\title{
Analysis of Factor Affecting e-Commerce Potential of any Coun- try using Multiple Regression
}

\author{
Ansar Waseem* \\ School of Business and Economics, University of Management Technology, Lahore, Pakistan
}

\begin{abstract}
The advancement of Information Technology and Telecommunication has opened new avenues for business. These astonishing developments have led to rapid diffusion of ecommerce which is gaining popularity around the globe and it is contributing to the economic growth of country. This study aims to develop an integrative model based on different factors which can affect the growth of e-commerce in any country. For this purpose, data of 145 countries for year 2014 was obtained from different sources. Nine different Multiple Regression Models were proposed by combination of different factors in order to analyze their relative effect on growth of e-commerce. Findings suggest that the sensitivity of the e-commerce potential was highest for GNI per Capita and Readiness Sub-Index, respectively. Similarly, other factors such as education level, urbanization and social media users were also found significantly associated with e-commerce potential. However, Cyber Security and Business Prospects were found to be statistically non-significant in few of the models. The paper concludes with few suggestions for government and policy makers to increase e-commerce growth in the country.
\end{abstract}

\section{Introduction}

During the last three decades, there has been a rapid advancement in information processing and telecommunication, and it has profound effects on the society and organization. Internet, along with information technology, has become an active source of conducting commercial activities (Jehangir et al., 2011; WASEEM et al., 2018). This has opened new avenues for business firms and led them to make drastic changes in their business activities. An ever growing number of internet users have encouraged many firms to enter in online business (Kumar et al., 2014) which has been warmly welcomed by their traditional customers. Consequently, an increasing number of conventional brick and mortar firms are also operating their business online. Use of internet for conducting businesses has given rise to a new form of transaction between buyers and sellers which is known as e-commerce. E-commerce is defined as sharing of business information, maintaining of business relationship and conducting of business transactions by means of telecommunication network (Zwass and Kendall, 1999).

Businesses that are conducted on the World Wide Web are different from the conventional brick and mortar businesses since there is no physical interaction between the buyer and the

*Corresponding author.

Email: ansarwasim436@gmail.com 
seller. Buyers can now shop from their homes without having to physically travel to shops. Ecommerce has extended unique prospects for firms and customers as it has reduced the need of physical markets (Arano, 2008). Now both buyers and sellers can transact in virtual market (Lawrence, 2011), and it has given new opportunities to both sellers and buyers.

In spite of its importance, incorporation of e-commerce in a country is gradual, evolutionary process and this process is affected by economic, socio-cultural, political and legal factors of that country (Hariharaputhiran, 2012; Rogers, 1995). However, a review of the extant literature in the field of e-commerce suggests that most of the studies have been limited to a single country (Ahmed and Hasan, 2016; Jalava and Pohjola, 2008; Jehangir et al., 2011; Kutlu and Özturan, 2008; Quayle, 2002; Samadi et al., 2015; Wong, 2003; Zafar et al., 2014) and individual factors have been considered in it (Blythe, 2008; Fianyi, 2016; Kyobe, 2008; Litondo and Ntale, 2013; Toraskar and Lee, 2006). Most of the studies have focused on technical factors such as information system, cyber security, marketing and business models (Jehangir et al., 2011). Little work is done in determining those national factors that may prove to be critical in determining the success or failure of e-commerce in a particular country. In order to fill this gap in literature, this study aims to develop integrative models through combination of different factors in order to see how these factors interact together in determining the potential of e-commerce in a country. Main focus of this study is Business to Consumer which is driven under and influenced by local factors of a countrys (Gibbs et al., 2003). Therefore, it is more suitable to develop an integrated framework that incorporates a number of different technological, social, and economic factors having potential affect in the growth of e-commerce.

This study is conducted to shortlist such factors which will help governments and their policy makers to take necessary steps for facilitation of e-commerce. E-commerce is still relatively new, and it is in infancy stage in developing countries where micro or small size enterprises could become driving force of a nations economy (Steinfield and Scupola, 2006). But, SMEs face economic, legal, technological, infrastructure and social impediments while entering into ecommerce (Jehangir et al., 2011). Therefore, growth in these SMEs has not been as rapid as other large firms (Pool et al., 2006). For developing countries, e-commerce can bring about a breakthrough by enhancing the growth of SMEs and bring positive social and economical changes. For this purpose, this study demonstrates the impact of technological, social and economic factors on e-commerce potential as these are most pertinent to the growth/inhibition of e-commerce especially in developed countries (Kshetri, 2007).

\section{E-Commerce: A review of literature}

Electronic business and commerce started in $90 \mathrm{~s}$ when few firms started to take advantage of growing internet use for carrying out different business functions. Tremendous growth in information technology and communication has encouraged the firms to conduct their business and financial transactions through internet. E-commerce and its related capabilities have enabled firms to create different value propositions (Zhu, 2004). It has changed the way businesses are conducted and it has put forth new ways of conducting business transactions (Harshita and Tanwar, 2016). Contrary to other technologies, internet and e-commerce is not limited to big enterprises. Small and medium firms are also using internet to expand their operations and these micro-electronic commerce initiatives are gaining popularity (Zhang et al., 2014). For SMEs, internet can reduce cost and enable them to operate in a particular market niche (Zafar et al., 2014). They can also present their product and service to global client which were previously inaccessi- 
ble (Lawrence, 2011). Such changes have presented unique opportunities for the business firms as well as a threat to their very existence if they are not embracing this immanent change.

Nowadays, internet has become an integral part of modern firms. Firms are using internet and social media before and after sales. It has also enabled firms to perform important non-financial activities at their own level at minimum price, which were hitherto either too cost ineffective or carried out by third party. These activities range from information about the product and services provided to the customers, online tracking of orders, and digital catalogues to customize any product to specific needs of the customers (Zhu, 2004). Firms are using internet as a tool to gather valuable information about their suppliers and competitors. Development in the Information and Communication Technology has assisted in reaping advantages from e-commerce. In addition, ICT is helpful in cost reduction, better customer relation and market niche development (Kutlu and Özturan, 2008). These ICTs have produced positive changes in participation of customers, product advertisement and promotion. All these factors combined with expansion in the field of ITC has encouraged firms to conduct their business online and become digital (Kumar et al., 2014).

All this is resulting in popularity of e-commerce among sellers. Firms can enter into online business at a comparatively lower cost as there is little capital cost associated with startup or subsequent advertisements of e-business. E-commerce gives firms a chance to directly interact with their customers through interactive websites (Ayo et al., 2011; Zhu, 2004). This direct interaction also helps in reducing costs of product and service which tends to be high in traditional business because of the market intermediaries. Moreover, conducting business through internet allows interaction with distant partners (Steinfield and Scupola, 2006). This can reduce the bargaining power of suppliers and stakeholders. Organizations that are using internet as a tool to conduct business online can reap benefits of lower cost, better customer service, and easier access to pertinent information (Quayle, 2002). Lastly, e-commerce has enabled firms to use internet for better information sharing, improved logistics, superior customer service and back-end integration ( $\mathrm{Zhu}, 2004)$.

On the other side, it has given a certain degree of luxury to buyers who can shop irrespective of their time and place. These benefits include easier access to information, comprehensive comparison between similar products, convenience in conducting purchase, and saving of time and money (Kaur and Kaur, 2015; Samadi et al., 2015). Now customers can make purchase and book their order online from virtually anywhere in the world. Many prospective buyers conduct an online search about products or services before making the actual purchase. E-commerce has extended greater bargaining power to the customers through in depth comparison between products. Better access to information about available products and services results in reduced transaction cost for customers (Pool et al., 2006). This has induced changes in the buying behavior of the customers, which has presented incentives for the business to move their business online (Jehangir et al., 2011).

Without doubt internet and e-commerce has proven to be of extreme use, people are adopted it rapidly. This has inspired firms operating in online business to make e-commerce more and more user friendly and interactive for their customer. However, there is a high degree of risk associated with e-commerce. These risks stem from certain characteristics of e-commerce as well as few intentional or unintentional practices being carried out in this business. These characteristics and practices act as cognitive barriers to adoption of online business (Kshetri, 2007). For example, the difficulties encountered in returning of sold goods (Ahmed and Hasan, 2016) create distrust among buyers. In addition, there is a severe lack of brand awareness of online firms. People have the habit to buy from well recognized brands because they doubt the level of 
service of unknown brand. These doubts are giving rise to various issues of trust among buyers (Samadi et al., 2015). As a result, all these factors inhibit growth of e-commerce.

\section{Factors affecting growth of e-commerce}

Aim of this paper is to investigate and shortlist factors which are important for spread of e-commerce in any country. For this purpose, certain technological, social and economic factors are considered. Due to time constraint, only a limited number of factors have been included in this study. These factors operate at national level and are widely cited in the literature of e-commerce. A brief description of these factors is as follows:

\subsection{Technological Factors}

\subsubsection{Infrastructure of Information Communication Technology}

An important national factor contributing towards the growth of e-commerce in a particular country is the infrastructure of Information Communication Technologies (ICT). ICT is defined as diverse set of technological tools and resources to create, disseminate, store, bring value addition and manage information (Nath, 2001). The explosion of e-commerce today can be attributed to the revolution in the field of ICT (Smith, 2009) since e-commerce is combination of progress in ITC with traditional institutional framework (Pool et al., 2006). Organizations are now using ICT to improve their logistic system (Rao et al., 2010), supply chain management and reverse logistics. ICT facilitates firms in improved coordination, better information processing, superior decision making, and effective data and knowledge management (Zafar et al., 2014). ICTs also provide means for interacting with customers, stakeholders, suppliers, dealers, business regulators as well as communicate with both downward and upward side of supply chain (Warkentin, 2001; Zhu, 2004). In short, e-commerce facilitated through ITC has become a potent weapon for organizations to achieve long term profitability and competitive advantage in the market (Jehangir et al., 2011).

Like most of the advanced technologies, e-commerce was originated in the developed countries. Companies in such countries took advantage of the infrastructure for ITC which was developed by their government. A major factor which contributes to lower diffusion of ecommerce in third world countries is their poor overall infrastructure in general and ICT infrastructure in particular. This hurt their ability to start business online (Sarokolaei et al., 2012). Thus, any government should work in providing the necessary infrastructure for the growth of ICT. A prominent example in this regard is Singapore where appreciable existing infrastructure of ICT has facilitated easy diffusion of e-commerce (Wong, 2003). In addition to infrastructure, it is imperative that the citizens of a country posses the required skills for effective use of modern technologies. Many entrepreneurs in the developing countries fail in e-commerce due to their lack of knowledge and skills in ICT (Zafar et al., 2014).

With a better infrastructure and skill level of the citizens, the usage of e-commerce will increase. This will encourage people to carry out majority of their routine purchases from internet which will further boost economic activity. Jalava and Pohjola (2008) demonstrated that in Finland the increase in multi level factor production caused due to growth in ITC was around $60 \%$ which was almost $66 \%$ more than that of electricity. Therefore, it can be concluded that infrastructure of ITC in a country coupled with better skill level of its citizen can enhance the growth of e-commerce. 


\subsubsection{Mobile Phone Subscription}

Mobile phone is one of the most preferred equipment for ICT. There has been an exponential increase in the mobile phone users throughout the world. The innovation of $3 \mathrm{G}$ and $4 \mathrm{G}$ communication system has turned mobile phone into an all round device. This has also led to the emergence of M-commerce, which is considered an extension of e-commerce. Any transaction, whether monetary or non-monetary, carried out with the help of wireless telecommunication is referred to as mobile commerce (Barnes, 2002). M-commerce complements e-commerce (Yin et al., 2016). In 2012, an increase of more than $50 \%$ in mobile commerce was observed (Zhang et al., 2014), which has in turn increased the volume of online business (Kim et al., 2015). Due to mobile phones, internet traffic to e-commerce websites has increased from 3\% to 37\% (Schöder et al., 2016). In 2013, people in US made $7.4 \%$ of their online purchases through tablets, whereas contribution of mobile phones for this purpose was 5.3\$ (Venkateswaran, 2013). These figures are likely to grow as more and more people are using mobile application for various online retail purchase. Resultantly, many firms such as E-bay, Amazon, etc. have developed their own mobile applications in order to capture a larger market segment. Mobile phones and tablets have become an important source to excess global e-market. Therefore, mobile phone subscription can have a positive effect on the growth of online sales.

\subsubsection{Social Networking Sites}

Social media is defined as an online platform which allows people to share their experiences and opinions with each other (Lai and Turban, 2008). The use of social networking sites is also on the rise. (Zhao et al., 2015) believe that rapid growth of social networking sites is blurring the boundary between e-commerce and social networking. Numbers of firms who are using social media to promote revenue are steadily increasing (Han and Kim, 2016). Firms are effectively using social media in creating brand and product awareness. Social networking sites such Facebook, Twitter, Instagram and many other similar websites help firms in socially relating with their target customers (Montague, 2011). Many social networking sites are being used by the sellers to interact with buyers. These websites provide an excellent platform for advertisement of product and service as they allow paid content and advertisement (Hariharaputhiran, 2012).

Another interesting use of social media is the spread of word of mouth which is an extension of Electronic Word of Mouth (EWOM). The latter term is described as an informal communication which tells customers about characteristics of product or service through digital means (Berger, 2014). The emergence of Web 2.0 has increased the User Generated Content (UGC) on networking sites (Yan et al., 2016) which is quickly becoming a wide source of word of mouth. After every shopping, customers share their experiences and opinions about their purchases on different social networking sites (Yan et al., 2016). Many people refer to these online reviews, blogs and other forms of UGC before making actual purchase (Cheung and Thadani, 2012) in order to improve their product/service selection related decision. Therefore, UGCs and EWOM have an impact on the buying decisions of people. However, there is a negative side to such endorsements as people are not aware of the authenticity and reliability of the reviewer (Yan et al., 2016). Therefore, organizations are giving due care to this and they are constantly monitoring different social forms to check their brand and product image (Kotler and Armstrong, 2010).

On the basis of above review of literature, we can propose our first hypothesis:

$H_{1}$ : Different technological factors such as Infra-structure of ICT, Number of Mobile Subscribers and Social Virtual Network Users are positively related with e-commerce potential. 


\subsection{Social Factors}

\subsubsection{Urbanization}

An understated factor that has promoted the use of e-commerce is the migration of people living in rural areas to urban settlements. Throughout the world, people are migrating to urban cities in order to get better education, health, jobs and business opportunities. They work relentlessly in order to have better earning and meet ends. Such people try to give much of their time to work and they are, thus, left with very little time to spend on shopping. In an attempt to save their time, they resort to online shops and place orders ranging from common grocery items to home appliances. Many firms are offering their product by keeping in view the specific needs of such customers. The development of ICTs has made matters simpler and people can save their time by shopping from online stores. Moss (1987) had predicted before time that good infrastructure of ICT in cities will help their residents in doing online shopping. Firms also use this infrastructure to their advantage (Steinfield and Scupola, 2006). On the other hand, people and SMEs working in the cities enjoy access to internet and better roads facilities (Kyobe, 2008). On the contrary, rural areas of countries are usually less developed due to lack of good roads and telecommunication infrastructure (Dhliwayo, 2008) and they have less access to computers and internet. This halts the growth of entrepreneur SMEs in rural areas.

Due to urbanization, industries usually form clusters in urban areas and cities (Breschi and Malerba, 2001). They are concentrated in a particular area to obtained geological benefits from it (Porter, 2000) or proximity to buyers and suppliers (Sonn and Storper, 2008). These clusters are important for economic activities in a particular region as buyers take advantage of low transportation cost for being closer to firms (Sonn and Storper, 2008). Therefore, urbanization is an unsung factor increasing the use of e-commerce.

\subsubsection{Education and Technical Literacy}

In addition to urbanization, education and technical, literacy level is another social factor which affects the use of internet and online shopping. Wu et al. (2016) consider employees with relevant knowledge of e-commerce to be critical for the success of any firm carrying out business online. The same reasoning can be extended to countries. Education and literacy level of entrepreneur of SMEs interested in conducting their business through internet also effect the growth of e-commerce (Kyobe, 2008). Taiwan government has managed to become leaders of B2C through the used technical oriented literature and scholarships which have equipped their citizen for better diffusion of e-commerce in the country (Ahmed and Hasan, 2016). On the contrary, low level of education of entrepreneurs can affect their ability to handle technology and make them more prone to cyber-attacks (Kyobe, 2008). Kumar et al. (2014) have argued that Generation $\mathrm{Y}$ is more connected and familiar with internet than their preceding generations. Due to their better education level and awareness, Generation $\mathrm{Y}$ is using internet for shopping and buying of products and services. To conclude, education level of citizens of a country can significantly increase the adoption process of e-commerce.

\subsubsection{Cyber Security}

Yet another important factor which can potentially be detrimental to the growth of e-commerce is the threat of online frauds and cyber crimes. E-commerce security entails protection against risks and threats that tend to target the sensitive information and system being used in ecommerce activities (Kyobe, 2008). As stated earlier, there is no physical interaction between 
buyers and sellers in online business (Gnanasekar, 2010). The perpetrators of cyber crime take advantage of this anonymity and they commit crimes to make illegal money for themselves. Payments in online businesses are made to firms own account or third party system. For this purpose, buyer has to provide his/her credentials and important personal information. This poses the threat of identity theft, stolen credit card number, stolen national security numbers and abuse of similar information. The situation is made worst by the development of sophisticated hacking software (Fianyi, 2016). Since mostly buyers in e-commerce and some sellers are ordinary people with little knowledge about cyber threats, they remain unable to detect such perils. These fraudulent practices are a serious challenge to e-commerce because the more an online business grows; higher are the chances of such malicious practices (Turban et al., 2015). Unfortunately, firms also give less attention to these security aspects and are somewhat complacent towards cyber threats (Kyobe, 2008). To make things worse, several governments have done little to protect their citizens from transaction disputes and online frauds. All these factors contribute towards low level of trust exhibited by the customers towards online transactions. For instance, Kumar et al. (2014) reports 60\% Indians dont trust online payment channels. At their own level, firms operating in online businesses should work hard to increase their technical capacity in combating this threat (Vorley and Rodgers, 2014). Similarly, governments should take appropriate steps to protect consumers interests by making strict legislation in this regard.

Based on above argument, our second hypothesis is given as under.

$\mathrm{H}_{2}$ :The social factors such as Urban Population, Expected Years of Schooling and Cyber Crime Security are positively related with e-commerce potential.

\subsection{Economic Factors}

\subsubsection{Income Level of Citizens}

Many studies have concluded that e-commerce is particularly less popular in developing countries. People in developed countries are more inclined towards shopping through online means. A major region is the economic progress and higher per capita income. According to Information Economy Report 2015, the top 10 countries with highest B2C revenue are those who enjoy higher GDP and GNI. In the same report, it is highlighted that largest internet retail companies in US, Europe, Asia and Latin America for 2012-13 are based in US, UK, Germany, China, Brazil and France. This shows that an active economy will provide more business opportunities to its nationals. Also, economic and financial factors decide whether venture capitalists have enough resources to start online business (Gibbs et al., 2003). Contrary to this, poor economy and lack of financial resources in developing countries have adversely affected spread of e-commerce (Lawrence, 2011). Lack of ability to generate constant streams of funds from their own resources or stockholder is a big reason in failure of e-business firms (Zafar et al., 2014). Furthermore, there exists a substantial difference in the business models for e-commerce between developing and developed countries (Jehangir et al., 2011). All these factors lead us to assume that level of income in a country will encourage its buyers and firms to venture into online business.

\subsubsection{Business Activities}

Advancement in e-commerce has enabled governments to expand business activities in their countries as ICTs have provided thrust to local and global business. Computer, internet and ICTs are quickly becoming part of any firms business setup (Hariharaputhiran, 2012). Countries are 
now effectively utilizing their previously untapped resources. Due to this, their economies are approaching the optimization state, resulting in improved economic status (Allen et al., 2001). Ecommerce helps in development of secondary and tertiary industries in the countries (Rao et al., 2010). These better business prospects will encourage firms and enter into online market to tap its advantage. However, the role of a stable political and economic system; and an effective legal system is essential for growth of e-business. Ahmed and Hasan (2016) noted that many countries such as Singapore, Taiwan, Malaysia, Thailand etc have used tax reliefs to encourage entrepreneurs and venture capitalists to start business. Contrary to this, various policies and red tapes regarding starting e-commerce have badly hurt Arab countries in online ventures. Therefore, the level of business opportunities in a country and incentive given to entrepreneurs has a positive effect on the growth of e-commerce.

\subsubsection{Logistics Network}

Lai and Turban (2008) regarded that e-commerce is marketing and distribution of goods and services through internet. This definition highlights the role of trade logistics and an efficient infrastructure in the advancement of e-commerce. But, this has gathered little attention in ecommerce related research (Wisner, 2003). Unlike conventional brick and mortar system, the online firms have to deliver varying quantities on order to their respective customers; therefore, an extensive and well managed logistic system is required (Rutner et al., 2003). Researchers have indicated that an efficient distribution system is an indicator of better customer service. Fontes et al. (2018) have proved a positive relation between logistic capabilities and firm performance in an e-market; thereby suggesting the importance of logistics in the success of e-commerce.

The above arguments lead us to hypothesize that:

$\mathrm{H}_{3}$ :Economic factors such as GNI per Capita, Logistic Performance Index Score and Distance to Frontier Score are positively related with e-commerce potential.

The above three hypotheses independently postulate about the role of different technological, social and economic factors in supporting or inhibiting growth of e-commerce in any country. It will be interesting to note how these three factors mutually reinforce each other in determining the overall potential of e-commerce in a country. H4: Different technological factors (Infra-structure of ICT, Number of Mobile Subscribers and Social Virtual Network Users), social factors (Urban Population, Expected Years of Schooling and Cyber Crime Security), and economic factors (GNI per Capita, Logistic Performance Index Score and Distance to Frontier Score) are positively related with e-commerce potential.

\section{Operationalizing and Data Sources}

This study is aimed at determining the country specific factors which may affect growth of e-commerce in a country. This is different from other empirical researches in e-commerce as the latter were more interested in determining the firm and customer specific factors, while none of them have taken into consideration the national factors which may increase online business activities. Therefore, the variables were divided into three categories.

1. Technological Factors

2. Social Factors

3. Economic Factors 
The Technological factors included infrastructure of ICT, Mobile Phone and Virtual Social Network. Data of Infrastructure of ICT and Use of Virtual Social Network was obtained from Global Information Technology Report for Year 2014. This report is published by World Economic Forum, and it ranks countries on the basis of Network Readiness Index which is an aggregated score of four sub-indices. For Infrastructure of ICT, Readiness sub-index was used. This sub-index is based on three pillars which are infrastructure, affordability and skills. Similarly, use of Virtual Social Network under the pillar of individual usage of ICT was used as a measure of social media usage. The measure of mobile phone usage was adopted from the Mobile cellular subscriptions (per 100 people). Data of this variable was obtained from World Bank site.

For social factors, Urbanization, Education Level and Cyber Security were considered as relevant constructs. Data of urban population (as a percentage of total population) was obtained from World Bank site. To measure education level of a country, Expected Year of Schooling score from Human Development Report was used. Global Cyber Security Index (GCI), developed by ABI Research, was used to represent the cyber security rating of a country.

For economical factors, Income Level, Logistic Capabilities and Business Opportunities were considered. Data of GNI per capita was obtained from Human Development Report. Information regarding logistics capabilities of country was gathered from Logistic Performance Index. For Business Opportunities, Distance to Frontier Score from Doing Business Report, published by World Bank, was used as measure.

For the dependent variable, e-commerce potential of a country was measured from UNCTAD B2C E-Commerce Index from Information Economy Report. This index explains the potential of a country in carrying out B2C e-commerce.

\section{Results}

Data of above mentioned variables for 145 countries were obtained from various sources as mentioned in Table No 1. Year 2014 was taken as the base year for data collection. Descriptive statistics was used to perform Uni-Variate Analysis on the variables. Means was used as a measure of central tendency; however, for those variables whose Skewness Index Coefficient was outside the permissible limit, Median was used. Standard Deviation was used to indicate spread of the variables. Results on these Descriptive Statistics of variables are shown in Table No 1. After performing Uni-Variate Analysis, Bi-Variate Correlation Analysis was carried out to check the association between variables. Pearson Correlation was used as it is the most appropriated variable in case of continuous variables. A strong correlation of E-Commerce Potential Score with other variables was found. All these relations were positive suggesting that all these variables have a positive effect on e-commerce potential. Furthermore, all relations were statistically significant. E-Commerce Potential Score has strongest correlation with the Readiness Sub-Index as the value of Pearson Correlation was greatest between these two variables. On the opposite side, E-Commerce Potential Score has the weakest relation with Mobile Phone Subscription. Results of Bi-Variate Correlation analysis are shown in Table No 2.

In order to prove hypotheses, Multiple Regression Analysis was used. Table No 3 shows the results of different Regression Models. Models 1, 2, 3 and 9 are used to test the research hypotheses while the remaining models are developed through combination of different variables. Each of these models was found to satisfy all requisite conditions of Regression Analysis.

The first model demonstrates the effect of technological factors such as infrastructure of 
Table 5.1: Descriptive Statistics of Variables

\begin{tabular}{|c|c|c|c|c|}
\hline Name of Variable & Data Source & No of obs & Mean/Median & Std. Dev. \\
\hline B2C e-commerce index & $\begin{array}{l}\text { Information Economy Re- } \\
\text { port }\end{array}$ & 122 & 49.24 & 24.17 \\
\hline Readiness Sub-Index score & $\begin{array}{l}\text { Global Information Technol- } \\
\text { ogy Report }\end{array}$ & 140 & 4.56 & 1.14 \\
\hline Mobile phone subscription & World Bank database & 149 & 110.18 & 38.11 \\
\hline Use of virtual social network & $\begin{array}{l}\text { Global Information Technol- } \\
\text { ogy Report }\end{array}$ & 140 & 5.48 & 0.72 \\
\hline Urban population & World Bank database & 149 & 58.87 & 22.75 \\
\hline $\begin{array}{l}\text { Expected years of schooling } \\
\text { in years }\end{array}$ & $\begin{array}{l}\text { Human Development Re- } \\
\text { port }\end{array}$ & 149 & 8.25 & 3.16 \\
\hline Cyber security index & Global Cyber Security Index & 145 & 0.35 & 0.22 \\
\hline Gni per capita & $\begin{array}{l}\text { Human Development Re- } \\
\text { port }\end{array}$ & 149 & $12190.00^{*}$ & $19,513.35$ \\
\hline Logistics performance index & World Bank database & 149 & $2.80^{*}$ & 0.76 \\
\hline Distance to frontier score & Doing Business & 149 & 63.03 & 12.47 \\
\hline
\end{tabular}

*Since the value of skewness index was outside the range of -1.3 to 1.3 therefore, median is taken as a measure of central tendency. For all others, value represents mean value.

ITC, mobile phone subscriptions and number of social networking site users. Un-standardized coefficient of all three variables has positive sign which shows that all these three factors are positively related with e-commerce potential. This result is consistent with views of Schöder et al. (2016) who regard growth of ITC, mobile phone and social media to have significant impact on e-commerce. Out of the three factors, infrastructure of ITC has the highest value of un-standardized coefficient which means that e-commerce potential is more sensitive to this variable. The result of Model No 1 shows that our first hypothesis has been proven.

The second model shows the impact of social factors on the success of e-commerce. The three variables involved were not only positively related with the e-commerce potential score but also statistically significant. This proves our $2^{\text {nd }}$ hypothesis. The overall strength of the model was pretty high which means that $80 \%$ variation in the value of E-Commerce Potential Score is described by these three variables. This model also demonstrates that among different social factors, e-commerce is most sensitive to cyber security.

Model No 3 shows that the third hypothesis is also supported as all three variables involved in it are positively related with e-commerce potential. Among all three variables, GNI per Capita had highest sensitivity towards e-commerce since its value of un-standardized coefficient was 35.5. The value of $\mathrm{R} 2$ for this model was 0.884 . This result gives a plausible account on why development of e-commerce is more conspicuous in developed countries such as USA, China, UK etc. (Pool et al., 2006). Citizens of these countries enjoy higher income level which promotes buying online. Moreover, superior business regulatory system in these countries is also 
Table 5.2: Correlation between Variables

\begin{tabular}{|c|c|c|c|c|c|c|c|c|c|}
\hline Name of Variable & 1 & 2 & 3 & 4 & 5 & 6 & 7 & 8 & 9 \\
\hline B2C e-commerce index & $1^{* *}$ & - & - & - & - & - & - & - & - \\
\hline Log GNI per capita & $0.846^{* *}$ & 1 & - & - & - & - & - & - & - \\
\hline Readiness sub-index score & $0.915^{* *}$ & $0.678^{* *}$ & 1 & - & - & - & - & - & - \\
\hline Mobile phone subscription & $0.555^{* *}$ & $0.527^{* *}$ & $0.571^{* *}$ & 1 & - & - & - & - & - \\
\hline Use of virtual social network & $0.801^{* *}$ & $0.628^{* *}$ & $0.780^{* *}$ & $0.531^{* *}$ & 1 & - & - & - & - \\
\hline Urban population & $0.733^{* *}$ & $0.693^{* *}$ & $0.645^{* *}$ & $0.587^{* *}$ & $0.627^{* *}$ & 1 & - & - & - \\
\hline Expected years of schooling & $0.859^{* *}$ & $0.587^{* *}$ & $0.865^{* *}$ & $0.559^{* *}$ & $0.701^{* *}$ & $0.604^{* *}$ & 1 & - & - \\
\hline Cyber security index & $0.659^{* *}$ & $0.503^{* *}$ & $0.646^{* *}$ & $0.349^{* *}$ & $0.553^{* *}$ & $0.484^{* *}$ & $0.542^{* *}$ & 1 & - \\
\hline Logistics performance index & $0.495^{* *}$ & $0.225^{* *}$ & $0.332^{* *}$ & 0.118 & $0.227^{* *}$ & $0.296^{* *}$ & $0.311^{* *}$ & $0.364^{* *}$ & 1 \\
\hline Distance to frontier & $0.749^{* *}$ & $0.587^{* *}$ & $0.743^{* *}$ & $0.465^{* *}$ & $0.662^{* *}$ & $0.553^{* *}$ & $0.696^{* *}$ & $0.610^{* *}$ & $0.327^{* *}$ \\
\hline
\end{tabular}

${ }^{* *}$ Correlation is significant at the 0.01 level (2-tailed).

Table 5.3: Different Regression Models

\begin{tabular}{|c|c|c|c|c|c|c|c|c|c|}
\hline Name of Variable & 1 & 2 & 3 & 4 & 5 & 6 & 7 & 8 & 9 \\
\hline Readiness sub-index score & $16.96^{* * *}(1.62)$ & - & - & $13.09^{* * *}(1.21)$ & - & - & $8.359^{* * *}(2.50)$ & $4.194^{* *}(2.11)$ & $8.594^{* * *}(2.51)$ \\
\hline Mobile phone subscription & $-0.059 *(0.037)$ & - & - & - & - & - & $-0.167^{* * *}(0.039)$ & - & $-0.126^{* * *}(0.03)$ \\
\hline Use of virtual social network & $6.384^{* *}(3.03)$ & - & - & $4.718^{* *}(2.84)$ & - & $14.669^{* * *}(3.91)$ & - & - & $4.629^{* * *}(1.79)$ \\
\hline Urban population & - & $0.235^{* * *}(0.07)$ & - & $0.217^{* * *}(0.047)$ & $0.115^{* *}(0.05)$ & - & - & $0.116^{* *}(0.45)$ & $0.114^{* * *}(0.06)$ \\
\hline Expected years of schooling & - & $4.419^{* * *}(0.44)$ & - & - & $1.774^{* * *}(0.39)$ & - & - & $1.179^{* *}(0.56)$ & $0.837(0.53)$ \\
\hline Cyber security index & - & $24.153^{* * *}(6.13)$ & - & - & - & $16.808^{* *}(8.22)$ & $2.466(4.97)$ & $0.208(3.99)$ & $-3.789(4.41)$ \\
\hline Log GNI per capita & - & - & $35.504^{* * *}(2.95)$ & - & $29.582^{* * *}(2.88)$ & - & $30.376^{* * *}(5.27)$ & $22.787^{* * *}(3.58)$ & $15.451^{* * *}(4.89)$ \\
\hline Logistics performance index & - & - & $4.085^{*}(2.06)$ & $4.525^{* * *}(1.27)$ & - & $4.990(3.61)$ & $3.744^{* * *}(1.23)$ & - & $2.76^{* *}(1.89)$ \\
\hline Distance to frontier score & - & - & $0.262^{* *}(0.11)$ & - & - & $0.579^{* * *}(0.20)$ & - & $0.104(0.11)$ & $0.108(0.11)$ \\
\hline Constant & $-56.124^{* * *}(11.15)$ & $-11.246^{* * *}(3.08)$ & $-98.071^{* * *}(5.48)$ & $-61.709^{* * *}(7.19)$ & $-89.771^{* * *}(7.58)$ & $-88.992^{* * *}(15.82)$ & $-88.071^{* * *}(10.75)$ & $-83.079^{* * *}(10.19)$ & $-89.962^{* * *}(12.02)$ \\
\hline No of Valid Obs & 117 & 120 & 116 & 109 & 115 & 111 & 107 & 104 & 105 \\
\hline Probability of Shipro-Wilk test & 0.527 & 0.192 & 0.105 & 0.066 & 0.098 & 0.052 & 0.062 & 0.053 & 0.213 \\
\hline Durban Watson Statistics & 1.922 & 2.076 & 1.932 & 1.817 & 1.802 & 2.164 & 1.886 & 1.964 & 1.886 \\
\hline Value of $\mathbf{R}^{2}$ & 0.837 & 0.796 & 0.884 & 0.885 & 0.905 & 0.698 & 0.907 & 0.919 & 0.923 \\
\hline
\end{tabular}

Note: Values represent un-standardized coefficients while those in parenthesis are standard deviation of unstandardized coefficients.

*** $p<0.01,{ }^{* *} p<0.05,{ }^{*} p<0.1$

important in the growth of e-commerce (Jehangir et al., 2011).

Model No 9 represents the effect of all variables on online business potential. This model shows that a unit increase in GNI per capita and Readiness Sub-Index produces a respective increase of 15.6 and 8.6 units in the value of e-commerce. In the same model, Use of Virtual Networking Sites and Urban Population are positively related, whereas Mobile Phone Subscription Score is negatively related. The remaining four variables were statistically insignificant. Result of this model partially supports our fourth hypothesis. This model has the highest value of R2 and this model explains $92 \%$ variation in the value of E-Commerce Potential Score. 
In the remaining models, different combinations of variables were used to examine their effect on the outcome. Models No 4, 7, and 8 demonstrate the importance of infrastructure and affordability of ITC in the growth of online business. In all these models, the score of Readiness Sub-Index was statistically significant and positively related with E-Commerce Potential Score. This is true since countries that have higher potential of e-commerce are characterized by superior infrastructure of ITC. For example, Singapore with better infrastructure and higher readiness was able to ensure diffusion of e-commerce at a faster pace (Wong, 2003). On the other hand, poor infrastructure of ICT is a biggest problem which developing countries face during the adoption of e-commerce. In most of these countries, a large population doesnt have access to internet (Papastergiou and Solomonidou, 2005) which is creating a digital divide in the country. Governments should take immediate steps to minimize this digital divide. Similarly, considerable effect of GNI per Capita on online business can be observed from Models 5, 7 and 8. In all these models, the value of un-standardized coefficients was very high. This confirms the notion that countries with higher income have more budding prospects for growth of e-commerce. Country with higher level of national income have different consumer behavior and business environment (Jehangir et al., 2011) as compared to developing countries. Their high level of income allows them to carryout bulk of their shopping from online market. This leads to creation of more online firms which in turn leads to more economic activities in the country.

Same is the case for Virtual Social Network which appears to be positively related with the potential for online business. Many people are now part of social networking sites. Taking advantage of this, online firms are using these sites for marketing and advertisement of their products. Scholars believe that social networking sites are being used as a platform for advertising for both traditional brick and online firms (Hariharaputhiran, 2012; Zhang et al., 2014). Firms are reaping good return from such advertisements as around $5 \%$ of all online sales are attributed to social media and volume of such sales are estimated to be around 14 billion (Schöder et al., 2016).

Urban population was found to be significantly associated with E-Commerce Potential Score. But, the value of un-standardized coefficient for this variable was low as compared to other variables which indicate its impact is not as strong as other variables. These results indicate that the recent global trend of urbanization will facilitate growth of e-commerce since people living in the urban areas resort to online shopping in order to save time. However, such benefits are not limited to urban population as people living in the rural areas of countries are also obtaining benefits from e-commerce (Samadi et al., 2015). Same is the case with education level which is found to be positively and significantly related with e-commerce. This supports previous studies investigating the role of education and e-commerce. For example, Naqvi (2009) has found a positive relationship between knowledge of computer, internet and similar capabilities and e-commerce.

Result of this study is aligned with the previous studies that Logistics Performance had a substantial effect on e-commerce. Off late, flexibility in both location and time of delivery has been demanded by customers (Schöder et al., 2016). For this purpose, an efficient logistic system is required. Therefore, importance of a reliable and extensive distribution network is evident in any online business (Rabinovich and Knemeyer, 2006) since it can facilitate or inhibit growth of such businesses.

Surprisingly, Cyber Security Index was insignificant in many of these models. This variable was significant when few variables where included in the model. However, inclusion of other variables renders cyber security non-generalisable. Likewise, the impact of Business Opportunities (Distance to Frontier) was very little and it was insignificant in the presence of variables 
such as Readiness Sub-Index and GNI per Capita.

\section{Recommendations}

Business conducted through internet presents equal opportunities to both developed and developing countries. Since every country can benefit from e-commerce, it has enabled developing countries to keep abreast with developed countries. The use of e-commerce can lead to economic growth of the country for it may provide a new direction for economic growth (Yin et al., 2016). Rao et al. (2010) in their research on relationship between Chinese e-commerce transactions and GDP have concluded that there is long term positive relation between e-commerce and economic development of China.

In order to do so, governments of these countries should develop social and economical policies that are supportive for e-commerce (Jehangir et al., 2011). Local, regional and national governments should work to build up necessary infrastructure and devise policies for the growth of ITC (Steinfield and Scupola, 2006), because this infrastructure has positive effect on the confidence level of important stakeholder (WASEEM et al., 2018). A better regulatory frame for online business can be beneficial for growth of e-commerce. Although this study could not establish the importance of cyber security in the growth of e-commerce, in spite this, the importance of cyber security cannot be ignored. Today, both buyers and sellers have serious reservations about the security of online transactions (Harshita and Tanwar, 2016). Therefore, dedicated efforts towards sophisticated legislation are required by governments to thwart fraudulent practices in e-commerce (Namazifard et al., 2015).

Likewise, higher education institutes should also customize their curriculum of e-commerce according to market demands. Wu et al. (2016) note that mangers of e-commerce firms complain about qualified e-commerce graduate while e-commerce graduates feel skeptical about appropriate job opportunities. Literature shows that e-commerce related education and curriculum should be more theory-driven (Toraskar and Lee, 2006). The curriculum of e-commerce should adopt a multi-disciplinary approach (Toraskar and Lee, 2006). There is a need to relate e-commerce education with business management (Tomkovick et al., 2000).

Similarly, firms should also develop innovative business models for e-businesses in order to attract customers. There is a strong need to develop trust between buyers and sellers which becomes more paramount in online shopping. Good quality of relationship will increase customer loyalty in e-businesses. In order to build customer loyalty, online firms should strive toward providing better quality service to their buyers by meeting or even exceeding their expectation (Kotler \& Armstrong, 2010). Use of ITCs can serve the purpose for firms. For instance, firms are using social media as a potent tool to attract large number of online customers. Therefore, development of dedicated apps can also be used to increase traffic towards online shopping sites.

Firms should also work to develop an efficient logistic network. In urban areas, there is a growing apprehension about increase in the level of air pollution caused due to large number of vehicles. Therefore, an environmental friendly logistic system is need of the time. For example, e-commerce firms can switch to horizontal cooperation and crowd logistics distribution points for supplying parcels to urban and highly dense areas (Verheyen, 2016). Such third party delivery arrangements can be used to overcome delivery and environment related problems. 


\section{Conclusions}

The aim of this study was to investigate the impact of different social, technological and economic factors on growth of e-commerce in a country. E-commerce Potential was found to be positively associated with different social, economic and technological factors. GNI per Capita was the most important factor in the growth of online business. The second most important factor was Readiness Sub-Index (which is an aggregated measure of Infrastructure of ICT, Affordability and Skills level). Variables such as Urban Population and Virtual Networking Sites were a significant predictor of E-Commerce Potential. However, the results of factors like Logistic Performance Score and Expected Years of Schooling were mixed as sometimes these variables become statistically insignificant. To utter surprise, Cyber Security had persuasive effect on ecommerce in few, cases but more often it was found to be non significant in many instances. Similarly, the impact of business prospects was found to be very little and non-generalisible.

\section{References}

Ahmed, J. U. and Hasan, H. (2016). Barriers to ecommerce adoption in syria: An empirical detection. World Journal of Business and Management, 2(1):41.

Allen, J. F., Byron, D. K., Dzikovska, M., Ferguson, G., Galescu, L., and Stent, A. (2001). Toward conversational human-computer interaction. $A I$ magazine, 22(4):27-27.

Arano, K. G. (2008). Electronic commerce adoption in west virginia's primary and secondary hardwood industries: Preliminary results. In Proceedings of the 2008 Southern Forest Economics Workers (SOFEW) Annual Meeting, pages 72-81.

Ayo, C., Adewoye, J., and Oni, A. A. (2011). Business-to-consumer e-commerce in nigeria: Prospects and challenges. African Journal of Business Management, 5(13):5109-5117.

Barnes, S. J. (2002). The mobile commerce value chain: analysis and future developments. International journal of information management, 22(2):91-108.

Berger, J. (2014). Word of mouth and interpersonal communication: A review and directions for future research. Journal of consumer psychology, 24(4):586-607.

Blythe, S. E. (2008). Armenias electronic document and electronic signature law: Promotion of growth in e-commerce via greater cybersecurity. Armenian Law Review.
Breschi, S. and Malerba, F. (2001). The geography of innovation and economic clustering: some introductory notes. Industrial and corporate change, 10(4):817-833.

Cheung, C. M. and Thadani, D. R. (2012). The impact of electronic word-of-mouth communication: A literature analysis and integrative model. Decision support systems, 54(1):461-470.

Dhliwayo, S. (2008). Experiential learning in entrepreneurship education: A prospective model for south african tertiary institutions. Education+ training, 50(4):329-340.

Fianyi, I. (2016). Curbing cyber-crime and enhancing e-commerce security with digital forensics. arXiv preprint arXiv: 1610.08369 .

Fontes, C. H. d. O., Freires, F. G. M., et al. (2018). Sustainable and renewable energy supply chain: A system dynamics overview. Renewable and Sustainable Energy Reviews, 82:247-259.

Gibbs, J., Kraemer, K. L., and Dedrick, J. (2003). Environment and policy factors shaping global ecommerce diffusion: A cross-country comparison. The information society, 19(1):5-18.

Gnanasekar, J. (2010). Enhanced multi agents based model for convergent business services.

Han, M. C. and Kim, Y. (2016). Can social networking sites be e-commerce platforms? Pan-Pacific Journal of Business Research, 7(1):24.

Hariharaputhiran, S. (2012). Challenges and opportunities of e-commerce. International Journal of 
Marketing, Financial, Services \& Management Research, 1(3):98-108.

Harshita, S. T. and Tanwar, S. (2016). Security issues and countermeasures of online transaction in e-commerce. In Handbook of Research on Modern Cryptographic Solutions for Computer and $\mathrm{Cy}$ ber Security, pages 273-302. IGI Global.

Jalava, J. and Pohjola, M. (2008). The roles of electricity and ict in economic growth: Case finland. Explorations in Economic History, 45(3):270-287.

Jehangir, M., Dominic, P., Khan, A., et al. (2011). Towards digital economy: the development of ict and e-commerce in malaysia. Modern Applied Science, 5(2):171.

Kaur, E. H. and Kaur, M. D. (2015). E-commerce in india-challenges and prospects. International Journal of Engineering and Techniques, 1(2):36-40.

Kim, S., Hong, J., and You, Y. (2015). an exploratory study on e-business risks due to the sector classification of small and medium-sized enterprises. Indian Journal of Science and Technology, 8(S7):406413.

Kotler, P. and Armstrong, G. (2010). Principles of marketing. Pearson education.

Kshetri, N. (2007). Barriers to e-commerce and competitive business models in developing countries: A case study. Electronic commerce research and applications, 6(4):443-452.

Kumar, D. et al. (2014). Malaysian y generation consumer research: Does gender and technology literacy affirmative towards e-commerce activities? Journal of Economics and Behavioral Studies, 6(12):906-918.

Kutlu, B. and Özturan, M. (2008). The usage and adoption of it among smes in turkey: An exploratory and longitudinal study. Journal of Information Technology Management, 19(1):12-24.

Kyobe, M. (2008). The impact of entrepreneur behaviors on the quality of e-commerce security: A comparison of urban and rural findings. Journal of global information technology management, 11(2):58-79.
Lai, L. S. and Turban, E. (2008). Groups formation and operations in the web 2.0 environment and social networks. Group Decision and negotiation, 17(5):387-402.

Lawrence, J. E. (2011). The growth of e-commerce in developing countries: an exploratory study of opportunities and challenges for smes. International Journal of ICT Research and Development in Africa (IJICTRDA), 2(1):15-28.

Litondo, K. O. and Ntale, F. (2013). Determinants of mobile phone usage for e-commerce among micro and small enterprises in the informal sector of kenya. International Journal of Applied Science and Technology, 3 (6): 16, 21.

Montague, I. B. (2011). Social network media in the forest products industry: A look at a new way of marketing. In In: Proceedings of the $3 \mathrm{rd}$ international scientific conference on hardwood processing; 2011 Oct. 16-18; Blackburg, VA. Blacksburg, VA: Virginia Polytechnic Institute and State University: 235-241., pages 235-241.

Moss, M. L. (1987). Telecommunications, world cities, and urban policy. Urban studies, 24(6):534546.

Namazifard, A., Amiri, B., Tousi, A., Aminilari, M., and Hozhabri, A. A. (2015). Literature review of different contention of e-commerce security and the purview of cyber law factors. In 2015 9th International Conference on e-Commerce in Developing Countries: With focus on e-Business (ECDC), pages 1-14. IEEE.

Naqvi, Z. F. (2009). Pakistan-india trade potential and issues. The Lahore Journal of Economics, 14:171.

Nath, V. (2001). Empowerment and governance through information and communication technologies: Women's perspective. The International Information \& Library Review, 33(4):317-339.

Papastergiou, M. and Solomonidou, C. (2005). Gender issues in internet access and favourite internet activities among greek high school pupils inside and outside school. Computers $\mathcal{E}$ Education, 44(4):377-393. 
Pool, P. W., Parnell, J. A., Spillan, J. E., Carraher, S., and Lester, D. L. (2006). Are smes meeting the challenge of integrating e-commerce into their businesses? a review of the development, challenges and opportunities. International Journal of Information Technology and Management, 5(2/3):97-113.

Porter, M. E. (2000). Location, competition, and economic development: Local clusters in a global economy. Economic development quarterly, 14(1):15-34.

Quayle, M. (2002). E-commerce: the challenge for uk smes in the twenty-first century. International Journal of Operations \& Production Management, 22(10):1148-1161.

Rabinovich, E. and Knemeyer, A. M. (2006). Logistics service providers in internet supply chains. California Management Review, 48(4):84-108.

Rao, Y., Zhang, K., and Li, L. (2010). The econometric analysis of the relationship between chinese e-commerce transactions and gdp. In 2010 International Conference on Management of e-Commerce and e-Government, pages 248-251. IEEE.

Rogers, E. M. (1995). Diffusion of innovations: modifications of a model for telecommunications. In Die diffusion von innovationen in der telekommunikation, pages 25-38. Springer.

Rutner, S. M., Gibson, B. J., and Williams, S. R. (2003). The impacts of the integrated logistics systems on electronic commerce and enterprise resource planning systems. Transportation $R e-$ search Part E: Logistics and Transportation Review, 39(2):83-93.

Samadi, B., Gharleghi, B., and Syrymbetova, M. (2015). An analysis of consumers' trust, logistic infrastructure and brand awareness towards e-commerce implementation in kazakhstan. International Journal of Business and Management, 10(10):96.

Sarokolaei, M. A., Rahimipoor, A., and Vakilzadeh, Z. (2012). The impact of technology and communication infrastructure on development of e-commerce in iran. International Journal of e-Education, e-Business, e-Management and $e$-Learning, 2(2):162.
Schöder, D., Ding, F., and Campos, J. K. (2016). The impact of e-commerce development on urban logistics sustainability. Open Journal of Social Sciences, $4(03): 1$.

Smith, K. T. (2009). Worldwide growth of ecommerce. E-Business (March), pages 29-34.

Sonn, J. W. and Storper, M. (2008). The increasing importance of geographical proximity in knowledge production: an analysis of us patent citations, 1975-1997. Environment and Planning A, 40(5):1020-1039.

Steinfield, C. and Scupola, A. (2006). Explaining ict infrastructure and e-commerce uses and benefits in industrial clusters: Evidence from a biotech cluster. In Proceedings of the 39th Annual Hawaii International Conference on System Sciences (HICSS'06), volume 8, pages 209b-209b. IEEE.

Tomkovick, C., LaBarre, J., Decker, R., Haugen, S., Hostager, T., Pathos, J., and Steiner, E. (2000). A cross-functional, multi-disciplinary approach to teaching e-commerce. Marketing Education Review, 10(3):43-52.

Toraskar, K. V. and Lee, P. C. B. (2006). A contextualist approach to the development of ecommerce education: an analysis of key issues and challenges. Journal of Information Technology Management, 17(2):1.

Turban, E., King, D., Lee, J. K., Liang, T.-P., and Turban, D. C. (2015). E-commerce security and fraud issues and protections. In Electronic Commerce, pages 457-518. Springer.

Venkateswaran, N. (2013). An empirical study on e-commerce applications growth opportunities and business prospects. International Research Journal of Business and Management, pages 89-96.

Vorley, T. and Rodgers, P. (2014). Home is where the business is: Incidents in everyday life and the formation of home-based businesses. International Small Business Journal, 32(4):428-448.

Warkentin, M. (2001). The next big thing in ecommerce. Decision Line, 32(1):7-10. 
WASEEM, A., RASHID, Y., WARRAICH, M. A., SADIQ, I., and SHAUKAT, Z. (2018). Factors affecting e-commerce potential of any country using multiple regression analysis. Journal of Internet Banking and Commerce, 24(2):1-28.

Wisner, J. D. (2003). A structural equation model of supply chain management strategies and firm performance. Journal of Business logistics, 24(1):126.

Wong, P.-K. (2003). Global and national factors affecting e-commerce diffusion in singapore. The information society, 19(1):19-32.

Wu, M., Wang, M., Soar, J., and Gide, E. (2016). Chinas e-commerce higher education: a 15 years review from international viewpoint. Open Journal of Social Sciences, 4:155-164.

Yan, Q., Wu, S., Wang, L., Wu, P., Chen, H., and Wei, G. (2016). E-wom from e-commerce websites and social media: Which will consumers adopt? Electronic Commerce Research and Applications, 17:62-73.

Yin, S., Wang, L., and Yang, J. (2016). An empirical study on urban e-commerce competitiveness of china. International Journal of Mobile Communications, 14(4):328-347.
Zafar, F., Ishaque, R., and Javaid, M. (2014). Use of ict and e-commerce towards achieving competitive advantages. European Journal of Research and Reflection in Management Sciences, 2(1):1-10.

Zhang, J.-H., Xu, Y.-J., and Zhang, Z. (2014). Ecommerce discipline teaching reform and general education. In 2014 International Conference on Management Science and Management Innovation (MSMI 2014). Atlantis Press.

Zhao, W. X., Li, S., He, Y., Chang, E. Y., Wen, J.R., and Li, X. (2015). Connecting social media to e-commerce: Cold-start product recommendation using microblogging information. IEEE Transactions on Knowledge and Data Engineering, 28(5):1147-1159.

Zhu, K. (2004). The complementarity of information technology infrastructure and e-commerce capability: A resource-based assessment of their business value. Journal of management information systems, 21(1):167-202.

Zwass, V. and Kendall, K. (1999). Structure and macro-level impacts of electronic commerce. Emerging Information Technologies: Improving Decisions, Cooperation, and Infrastructure, Sage, Beverly Hills, CA, pages 289-315. 